\title{
ANALISIS UANG MUKA DALAM AKAD MURABAHAH PADA KREDIT PEMILIKAN RUMAH (Studi Pada BNI Syariah KCP JABABEKA Cikarang Bekasi)
}

\author{
Listian Indriyani Achmad1, Tri Sulistiana ${ }^{2}$ \\ 1 Universitas Pelita Bangsa, listian.achmad@pelitabangsa.ac.id \\ 2 Universitas Pelita Bangsa, trisulist27@gmail.com
}

\section{A R T I C L E I N F O}

Article history:

Received : 17/03/2021

Revised : 17/03/2021

Accepted: 02/04/2021

Key words:

Down Payment; Financing; Murabahah Agreement; Home Ownership Credit

DOI:

Doi.org/10.37366/jespb.v6i01.177

\begin{abstract}
A B S T R A C T
According to the Classical Islamic Literatures, down payment is clearly known as Urban in Arabic, or in Bahasa accepted by Panjar, which means an initial agreed contract into a transaction. Islamic Scholars arguably have different opinions in implementing down payment as a method in the transaction. There are some scholars who do not agree to put down payment as a particular way in the transaction, but others do. However, by exercising the quality of specific reasoning that is applied, and also the fact of the acceptance of the system of transaction, therefore this method of payment is generally accepted.

The first objective of this study is to determine the down payment mechanism and implementation of KPR financing with a murabahah contract at BNI Syariah KCP JABABEKA Cikarang Bekasi which is contained in the Griya iB Hasanah product. Second, to find out the settlement steps in case of problematic or bad financing. The three views of Islamic law in the perspective of muamalah figh towards down payments in a murabahah contract on a KPR at BNI Syariah KCP JABABEKA Cikarang Bekasi. This type of research is qualitative research. The data used are primary and secondary data. Primary and secondary data were obtained from observations, interviews, documentation, field studies, and from existing literature.

The results of this study are advances in murabahah contracts on KPR in BNI Syariah which refer to the DSN-MUI Fatwa Number 13 of 2000 concerning advances in murabahah. It seems that the fatwa is influenced by the thoughts / opinions of Imam Ahmad and his followers who allow buying and selling transactions using advances, then referring to the existing regulations of the OJK, the regulator of BI, that every financing, both conventional and sharia, must have an advance.
\end{abstract}

\section{A B S T R A K}

Menurut literatur Islam klasik, uang muka atau Down Payment (DP) sebenarnya dalam bahasa Arab dikenal dengan Urban, atau dalam bahasa diterima sebagai Panjar, yaitu kontrak yang disepakati diawal transaksi. Para ulama Islam memiliki pendapat yang berbeda dalam menerapkan uang muka sebagai metode dalam transaksi. Ada beberapa ulama yang tidak setuju untuk menempatkan uang muka sebagai cara tertentu dalam transaksi dan ada juga yang menyetujuinya. Oleh karena itu, penerapan sistem pembayaran seperti ini akan memudahkan segala transaksi jual beli, sehingga metode pembayaran yang berlaku secara umum dapat diterima. 
Tujuan penelitian ini yang pertama adalah untuk mengetahui mekanisme uang muka (DP) dan pelaksanaan pembiayaan KPR dengan akad murabahah di BNI Syariah KCP JABABEKA Cikarang Bekasi yang terdapat pada produk Griya iB Hasanah. Kedua, untuk mengetahui langkah penyelesaian jika terjadi pembiayaan bermasalah atau macet. Ketiga pandangan hukum Islam dalam perspektif fiqih muamalah terhadap uang muka dalam akad murabahah pada KPR di BNI Syariah KCP JABABEKA Cikarang Bekasi. Jenis penelitian yang digunakan adalah penelitian kualitatif. Data yang digunakan adalah data primer dan sekunder. Data primer dan sekunder didapat dari hasil observasi, wawancara, dokumentasi, studi lapangan, dan dari literatur yang ada.

Hasil penelitian ini yaitu uang muka dalam akad murabahah pada KPR di BNI Syariah adalah merujuk pada Fatwa DSN-MUI Nomor 13 Tahun 2000 tentang uang muka dalam murabahah. Tampaknya fatwa tersebut dipengaruhi oleh pemikiran/pendapat Imam Ahmad beserta para pengikutnya yang membolehkan transaksi jual beli dengan menggunakan uang muka, kemudian merujuk pada peraturan yang sudah ada dari OJK, regulator dari BI, bahwa setiap pembiayaan baik konvensional maupun syariah itu harus ada uang muka.

\section{PENDAHULUAN}

Bank adalah badan usaha yang bergerak dalam bidang keuangan dengan tiga bentuk kegiatan, yaitu menghimpun dana dari masyarakat, menyalurkan dana kepada masyarakat dan memberikan jasa-jasa lainnya (Kuncoro, 2000: 68). Bank menjalankan berbagai strategi agar masyarakat mau menyimpan uangnya di bank. Jenis simpanan yang dapat dipilih oleh masyarakat adalah simpanan giro, tabungan, dan deposito yang masing-masing memiliki kelebihan dan keuntungan tersendiri. Menyalurkan dana adalah memberikan kembali dana yang diperoleh melalui simpanan giro, tabungan, dan deposito kepada masyarakat dalam bentuk pembiayaan bagi bank syariah. Maka bank sangat memegang peranan penting dalam menyalurkan pembiayaan terutama pada usahausaha yang sangat membutuhkan pertambahan modal (startup). Sedangkan jasa-jasa lainnya adalah kegiatan menghimpun dana dan menyalurkan dana kepada masyarakat, contohnya adalah transfer (pemindahan uang), clearing (jasa kliring), jasa safe deposit box, dan lain sebagainya.

Selain itu, bank menyalurkan ke masyarakat dalam bentuk kredit dan atau bentuk-bentuk lainnya dalam rangka meningkatkan taraf hidup rakyat banyak (Hasibuan, 2008: 7). Beberapa kegiatan perbankan yang menjadi permasalahan dalam penelitian ini diantaranya mengenai kegiatan penyaluran kredit kepada masyarakat atau nasabah. Banyaknya anggota masyarakat yang memutuskan mengambil kredit pada suatu bank akan memberikan pengaruh yang besar terhadap keuntungan suatu bank. Disebabkan karena laba yang didapat oleh suatu perbankan salah satunya adalah dari suku bunga kredit yang diambil oleh para nasabah. Kemudian proses pengambilan kredit oleh seorang nasabah itu sendiri terjadi ketika seorang nasabah memutuskan untuk mengambil kredit pada suatu bank. Keputusan nasabah dalam mengambil kredit merupakan salah satu proses yang ada dalam aktivitas perbankan, setelah mempertimbangkan kemudian memilih satu alternatif dari beberapa alternatif yang ada. Adanya perbedaan jumlah nasabah yang memutuskan untuk mengambil kredit pada suatu bank di bank konvensional dan bank syariah menarik untuk diteliti.

Rumah merupakan kebutuhan pokok manusia, sebagaimana halnya makanan dan pakaian, rumah memiliki arti penting bagi sebuah keluarga karena rumah merupakan tempat untuk istirahat dan mencurahkan kasih sayang setelah sibuk bekerja atau beraktifitas di luar. Maka tidak heran apabila permintaan rumah tiap tahun terus bertambah. 
Namun harga rumah yang terus membumbung menyebabkan jarang orang mampu membeli rumah secara tunai. Peluang inilah yang dimanfaatkan oleh banyak lembaga pembiayaan perbankan untuk menawarkan produk konsumtif yang banyak dikenal dengan kredit pemilikan rumah (KPR). Berbagai fasilitas kemudahan mulai dari proses pengajuan, keringanan biaya administrasi, rendahnya tingkat suku bunga dan sebagainya ditawarkan sebagai daya tarik. Sayangnya suku bunga bank yang fluktuatif dan tidak pasti terkadang membuat orang merasa ragu untuk mengambil kredit pemilikan rumah (KPR) dari perbankan (Fatimah, 2017).

KPR merupakan salah satu jenis layanan yang diberikan bank kepada para nasabah yang berharap mendapatkan pelayanan untuk mendapatkan pinjaman dalam pemberian kredit perumahan. KPR muncul karena adanya kebutuhan yang tinggi dikalangan masyarakat untuk dapat memiliki rumah tanpa diimbangi dengan peningkatan daya beli di masyarakat. KPR sendiri pada awalnya merupakan salah satu produk yang dikeluarkan oleh bank konvensional. Akan tetapi, seiring dengan perkembangannya, juga banyak dilakukan oleh perbankan syariah. Produk KPR yang ada pada perbankan syariah pada dasarnya berbeda dengan KPR yang ada di perbankan konvensional. Perbedaan ini dapat terjadi karena terdapat perbedaan prinsip antara perbankan syariah dengan perbankan konvensional. Dalam perbankan syariah biasa dikenal konsep berbasis bagi hasil dan juga perdagangan. Sedangkan dalam perbankan konvensional, dikenal sistem yang berbasis bunga. Dalam produk yang biasa dikenal dengan nama KPR syariah ini terdapat beberapa karakteristik yang berbeda. Diantaranya adalah pemberlakuan sistem kredit yang ada pada perbankan konvensional sementara pada perbankan syariah konsep KPR syariah menggunakan beberapa akad yaitu murabahah, ijarah muntahiah bit-tamlik, dan juga musyarakah mutanaqisah. Yang menjadi masalah adalah bahwa banyak masyarakat yang beranggapan bahwa produk KPR yang dikeluarkan oleh bank syariah merupakan produk yang tidak berbeda dengan yang dikeluarkan oleh bank konvensional. Hasil riset yang dilakukan oleh Alwi
(2011) menunjukkan bahwa pemasaran produk yang dikeluarkan oleh bank syariah, khususnya KPR sering kali mendapatkan tantangan dengan fakta bahwa pemahaman masyarakat masih sering terganggu dengan bank konvensional. Apalagi fakta menunjukkan bahwa masyarakat lebih banyak mengenal bank konvensional dibandingkan dengan bank syariah (Heykal, 2014).

Konsep KPR tanpa riba tidak dipahami dengan cara yang sama oleh setiap orang. Tidak sedikit orang yang menganggap bahwa ketiadaan bunga (interest) sudah merupakan pemahaman yang tuntas tentang konsep tanpa riba. Padahal riba bisa muncul dari aktivitas lain yang sayangnya tidak banyak disadari oleh masyarakat. Sebenarnya bukan hanya konsep tanpa riba saja yang perlu dipahami, disadari, dan diwaspadai oleh masyarakat. Keberadaan uang muka atau Down Payment (DP) adalah sebuah keniscayaan bagi suatu pembiayaan atau kredit bagi kepemilikan rumah. Biasanya, bank akan memberikan pinjaman sebesar kebutuhan dengan catatan memberikan DP sekitar 20\%-30\% dari total kebutuhan pembiayaan. Keharusan pemilik usaha untuk menyediakan dana pendamping sebesar 20\%-30\% dari total kebutuhan pembiayaan ini, sesungguhnya sama dengan perlunya DP dalam kredit/pembiayaan kepemilikan rumah (Fatimah, 2017).

Pada pelaksanaan pembiayaan akad murabahah pada KPR di bank terdapat beberapa aturan dan persyaratan. Kewajiban angsuran yang tidak dilunasi selambat-lambatnya pada tanggal jatuh tempo pembayaran angsuran merupakan tunggakan angsuran. Atas tunggakan dikenakan denda sebesar presentasi yang telah disepakati dalam akad atas angsuran yang tertunggak diperhitungkan sejak jatuh tempo pembayaran angsuran sampai saat dimana seluruh tunggakan dilunasi. Berdasarkan Fatwa DSN MUI Nomor 17/DSN-MUI/IX/2000 tentang sanksi atas nasabah mampu yang menunda-nunda pembayaran, terdapat point yang berbunyi "nasabah yang tidak/belum mampu membayar disebabkan force majeur tidak boleh dikenakan sanksi" (Fatimah, 2017). 
Penelitian yang sebelumnya tentang uang muka, dari Panji Adam. 2017. “Analisis Terhadap Fatwa Dewan Syariah Nasional (DSN) MUI Nomor 13 Tahun 2000 Tentang Uang Muka Dalam Murabahah". Hasil kesimpulan menunjukan bahwa: (1) pendapat yang kuat mengenai jual beli 'urbun adalah pendapat yang membolehkan, dan jual beli dengan menggunakan uang muka hukumnya adalah boleh. (2) Dasar hukum yang digunakan oleh DSN-MUI masih menggunakan dalil-dalil umum dalam menetapkan fatwa tersebut, serta metode istinbat yang digunakan adalah metode maslahat dan 'urf. Menurut Syamsul Anwar, konsep 'urbun (uang muka) dalam Fatwa Dewan Syariah Nasional (DSN) MUI ini lebih cocok dikualifikasikan sebagai ganti rugi berdasarkan kesepakatan dengan pembayaran awal dari pada 'urbun dengan alasan bahwa: Pertama, pemotongan uang muka oleh LKS dalam hal nasabah membatalkan akad murabahah didasarkan pada besarnya kerugian dialaminya, sehingga apabila 'urbun itu lebih besar dari kerugian LKS, sisanya dikembalikan kepada nasabah dan apabila lebih kecil, LKS dapat meminta tambahan kekurangannya. Kedua, dalam konsiderannya, DSN tidak menyinggung hadits larangan 'urbun. Ketiga, sebaliknya fatwa tersebut mengutip hadits tentang syarat (klausul) perjanjian, kaum muslimin setia kepada syarat-syarat mereka, dan hadits tentang ganti rugi, tidak boleh merugikan diri sendiri dan tidak boleh merugikan orang lain. (3) Fatwa DSNMUI tentang uang muka dalam murabahah dipengaruhi oleh pemikiran Imam Ahmad dan para pengikutnya yang membolehkan jual beli dengan menggunakan uang muka.

\section{Rumusan Masalah}

Berdasarkan uraian pada latar belakang yang telah dijabarkan di atas, maka penulis merumuskan masalah sebagai berikut:

1) Bagaimana mekanisme sistem uang muka dalam akad murabahah pada KPR di BNI Syariah KCP JABABEKA Cikarang Bekasi?

2) Bagaimana langkah penyelesaian jika terjadi pembiayaan bermasalah atau macet dalam akad murabahah pada KPR di BNI Syariah KCP JABABEKA Cikarang Bekasi?
3) Bagaimana pandangan hukum Islam dalam perspektif fiqih muamalah terhadap uang muka dalam akad murabahah pada KPR di BNI Syariah KCP JABABEKA Cikarang Bekasi?

\section{Tujuan Penelitian}

Berdasarkan rumusan masalah di atas, maka penelitian ini bertujuan sebagai berikut:

1) Untuk mendeskripsikan bagaimana mekanisme sistem uang muka dalam akad murabahah pada KPR di BNI Syariah KCP JABABEKA Cikarang Bekasi.

2) Untuk mendeskripsikan bagaimana langkah penyelesaian jika terjadi pembiayaan bermasalah atau macet dalam akad murabahah pada KPR di BNI Syariah KCP JABABEKA Cikarang Bekasi.

3) Untuk mendeskripsikan bagaimana pandangan hukum Islam dalam perspektif fiqih muamalah terhadap uang muka dalam akad murabahah pada KPR di BNI Syariah KCP JABABEKA Cikarang Bekasi.

\section{TINJAUAN TEOIRITIS}

\section{Uang Muka (Down Payment)}

Uang muka (Down Payment) dalam istilah figih adalah 'urbun atau 'urban. Adapun arti dasar kata 'urbun dalam bahasa Arab adalah meminjamkan atau memajukan. Secara etimologis 'urbun berarti sesuatu yang digunakan sebagai pengikat jual beli. Secara bahasa artinya, kata jadi transaksi dalam jual beli. Uang muka adalah sejumlah uang yang dibayarkan terlebih dahulu sebagai tanda jadi pembelian, panjar, persekot (Dagun Save, 1997).

\section{Akad}

Akad adalah salah satu prinsip muamalah adalah 'an tharadhin atau asas kerelaan atau konsensualisme para pihak yang melakukan akad. Asas konsensualisme menekan adanya kesempatan yang sama bagi pihak untuk menyatakan keinginannya dalam melakukan transaksi. Dalam Islam suatu akad baru lahir setelah dilaksanakan pernyataan kehendak penawaran (ijab) dan kehendak penerimaan (qabul). Kerelaan merupakan 
persoalan batin yang sulit diukur kebenarannya, maka manifestasi dari suka sama suka itu diwujudkan dalam bentuk akad. Akadpun menjadi salah satu proses dalam pemilikan sesuatu.

Dalam industri keungan syariah terdapat berbaagai macam produk beserta akadnya. Menurut Darsono (2017), akad yang berhubungan dengan kegiatan usaha keungan syariah dapat digolongkan kedalam transaksi untuk mencari keuntungan (tijari) dan transaksi tolong menolong yang tidak untuk mencari keuntungan (tabarru').

\section{Murabahah}

Murabahah adalah suatu skema jual beli antara penjual dan pembeli atau dalam dunia perbankan antara bank dan nasabah, dimana nasabah ingin membeli suatu barang kepada pihak bank, dan bank akan membeli dan menjual kembali kepada nasabah dengan keuntungan pada awal perjanjian yang disepakati kedua belah pihak. Skema pembiayaan ini sangat banyak dijumpai pada model pembiayaan pada bank syariah, dalam skema ini bank akan mendapatkan keuntungan dari penjualan suatu barang bukan dari kelipatan kredit seperti bank konvensional.

Adapun rukun-rukun dalam murabahah (Idri, 2016: 172):

a. Penjual $\left(b a^{\prime} i\right)$. Penjual adalah pelaku yang akan menjual suatu aset/barang kepada pembeli.

b. Pembeli (musytari). Pembeli adalah pelaku yang akan membeli suatu aset/barang dari penjual. Pembeli dan penjual adalah dua pelaku yang akan melakukan suatu transaksi.

c. Ijab qabul. Ijab qabul adalah suatu perbuatan/kesepakatan baik secara percakapan atau secara tulisan yang akan mengikat kedua pelaku transaksi (penjual dan pembeli). Pelaku ijab dalam proses murabahah yaitu pihak penjual (bank) dan pelaku qabul yaitu pembeli (nasabah).

d. Barang yang diperjualbelikan (ma'qud 'alayh). Objek yang diperjualbelikan harus jelas, karena objek tersebut menjadi salah satu hal yang membuat terjadinya suatu kesepakatan/akad.
Sedangkan syarat-syarat dalam murabahah (Antonio, 2001: 102):

a. Penjual memberitahu biaya modal kepada nasabah.

b. Kontrak pertama harus sah sesuai dengan rukun yang ditetapkan.

c. Kontrak harus bebas dari riba.

d. Penjual harus menjelaskan kepada pembeli bila terjadi catatan atas barang sesudah pembelian.

e. Penjual harus menyampaikan semua hal yang berkaitan dengan pembelian, misalnya jika pembelian dilakukan secara utang.

\section{Kredit Pemilikan Rumah (KPR)}

Dalam bisnis konvensional KPR diartikan sebagai kredit pemilikan rumah yaitu kredit yang digunakan untuk membeli rumah atau untuk kebutuhan konsumtif lainnya dengan jaminan agunan berupa rumah. Sedangkan pengertian KPR Syariah menurut OJK, yaitu Kepemilikan Pembiayaan Rumah yang dapat berupa pembiayaan jangka pendek, menengah atau panjang guna membiayai pembelian rumah tinggal, baik baru ataupun bekas dengan prinsip/ akad (murabahah) atau dengan akad lainnya.

Griya iB Hasanah adalah fasilitas pembiayaan konsumtif yang diberikan kepada anggota masyarakat untuk membeli, membangun, merenovasi rumah (termasuk ruko, rusun, rukan, apartemen dan sejenisnya), dan membeli tanah kavling serta rumah indent, yang besarnya disesuaikan dengan kebutuhan pembiayaan dan kemampuan membayar kembali masing-masing calon nasabah. KPR ini berbeda dengan sistem KPR biasa yang ditawarkan oleh bank konvensional. KPR Griya iB Hasanah adalah KPR yang berkonsep syariah yang secara ketentuan harus terhindar dari praktek maisir (perjudian), gharar (ketidakjelasan), riba (tambahan), dan batil (ketidakadilan). Bank membeli barang yang diperlukan nasabah atas nama bank sendiri, dan pembelian ini harus sah dan bebas riba. Bank kemudian menjual barang tersebut kepada nasabah (pemesan) dengan harga jual senilai harga beli ditambah keuntungannya. Dalam kaitan ini bank harus memberitahu secara jujur harga pokok barang kepada nasabah berikut biaya yang diperlukan. Nasabah kemudian membayar harga 
barang yang telah disepakati tersebut pada jangka waktu tertentu yang telah disepakati. Untuk mencegah terjadinya penyalahgunaan atau kerusakan akad tersebut, pihak bank dapat mengadakan perjanjian khusus dengan nasabah.

\section{Kerangka Pikir}

Untuk menggambarkan penjabaran dari latar belakang penelitian ini dapat dituangkan dalam kerangka pemikiran sebagai berikut:

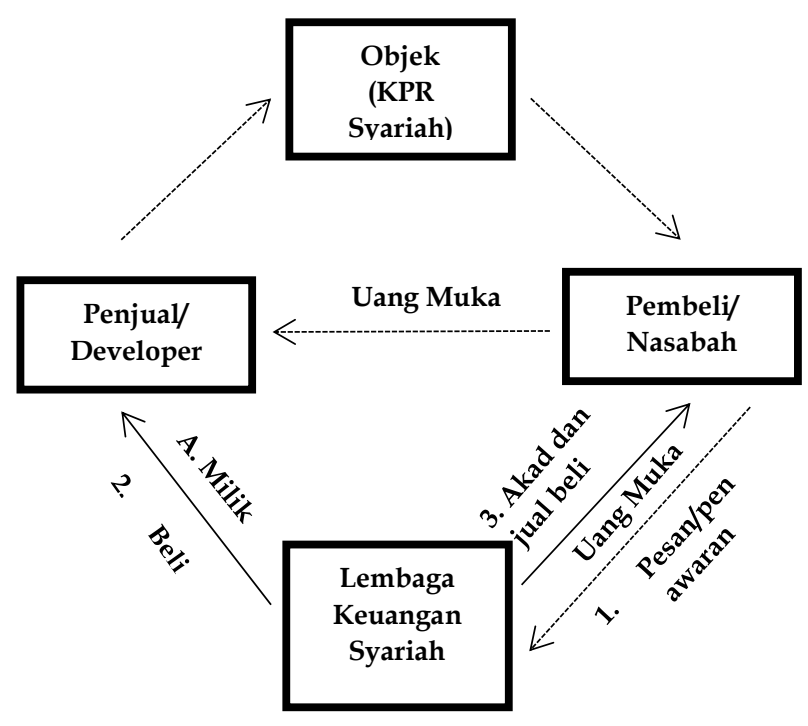

Gambar 1. Kerangka Pikir

\section{METODE PENELITIAN}

Pendekatan yang digunakan pada penelitian ini adalah kualitatif dan jenis penelitiannya adalah menggunakan jenis penelitian lapangan (memakai studi kasus). Penelitian ini dilakukan di BNI Syariah KCP JABABEKA Cikarang Bekasi. Peneliti melakukan pengambilan sampel dengan menggunakan teknik purposive sampling, yaitu teknik pengambilan sampel sumber data dengan pertimbangan tertentu. Pertimbangan tersebut misalnya orang tersebut dianggap paling tahu tentang apa yang diteliti. Narasumber dan ahli perbankan syariah dalam penelitian ini adalah pegawai atau staff di BNI Syariah, nasabah dan pakar ahli syariah.

\section{HASIL DAN PEMBAHASAN}

Dalam praktiknya, apabila sejumlah uang yang dibayarkan dimuka oleh seseorang pembeli barang kepada si penjual, bila transaksi tersebut dilanjutkan, maka uang muka tersebut dimasukkan ke dalam harga pembayaran. Namun apabila tidak jadi atau batal, maka uang tersebut menjadi milik si penjual. Dalam bentuk praktik yang lain, apabila seseorang pembeli menyerahkan sejumlah uang dan menyatakan bahwa apabila saya ambil barang tersebut, maka ini adalah bagian dari nilai harga, apabila tidak jadi maka uang DP tersebut untukmu.

Dalam perspektif fiqih, para ulama berbeda pendapat dalam status hukum praktik urban atau Down Payment (DP). Secara umum para ulama terbagi ke dalam dua pendapat yaitu:

Pendapat pertama, para ulama yang tidak membenarkan praktik urban. Menurut pendapat mayoritas ulama yang terdiri dari pandapat Hanafiyah, Malikiyah, dan Syafiiyyah bahwa urban tidak sah. Ada beberapa argumen yang dikemukakan para ulama yang melarang transaksi dengan urban yaitu pertama, adanya hadits yang secara jelas redaksinya melarang praktik urban. Hadits tersebut menyebutkan bahwa Nabi Muhammad SAW melarang jual beli urban. Walapun para ulama hadits menilai hadits ini dhaif (lemah), namun kelemahannya terletak pada sanad bukan matannya. Kedua, bahwa transaksi tersebut termasuk dalam kategori memakan harta orang lain secara batil, karena disyaratkan bagi si penjual tanpa ada kompensasinya. Padahal memakan harta orang lain adalah haram dan hal tersebut sudah ditegaskan oleh Allah SWT dalam al-Qur'an yang artinya bahwa orang-orang yang beriman jangan saling memakan harta dengan jalan yang batil, kecuali dengan jalan perniagaan yang berlaku secara suka sama suka. Ketiga, bahwa dalam transaksi urban, terdapat dua syarat yang batil yaitu syarat memberikan uang muka atau panjar dan syarat mengembalikan barang transaski dengan perkiraan salah satu pihak tidak ridho. Praktik ini dianggap sama dengan hak pilih terhadap hal yang tidak diketahui (khiyar al-majhul). 
Pendapat kedua, adalah pendapat yang membolehkan. Menurut kalangan Hanabilah bahwa transaksi dengan urban dibenarkan dengan beberapa alasan pertama, bahwa hadits yang dijadikan sebagai dasar bagi para ulama yang tidak membolehkan jual beli urban adalah hadits yang lemah, sehingga tidak dapat dijadikan sandaran dalam melarang bentuk jual beli tersebut. Disamping itu ada sebuah atsar yang menceritakan bahwa Nafi bin Harits pernah membelikan sebuah bangunan penjara untuk Umar dari Shafwan bin Umayyah (dengan ketentuan) apabila Umar suka. Apabila tidak, maka Shafwan mendapatkan uang yang sekian dan sekian. Kedua, bahwa panjar atau uang muka adalah kompensasi dari penjual yang menunggu dan menyimpan barang transaksi selama beberapa waktu. Tentu saja ia akan kehilangan sebagian kesempatan berjualan. Ucapan orang yang mengatakan bahwa panjar itu telah dijadikan syarat bagi penjual tanpa ada imbalannya adalah ucapan yang tidak sah. Ketiga, bahwa tidak sah analogi atau qiyas praktik jual beli urban dengan khiyar al-majhul, karena syarat dibolehkan adanya uang panjar adalah dibatasinya uang waktu menunggu. Dengan dibatasinya waktu pembayaran, maka analogi tersebut menjadi batal.

Para ulama hukum Islam kontemporer memilih pandangan fukaha Hanbali dan membenarkan praktik urban sebagai suatu yang tidak bertentangan dengan hukum Islam, dengan alasan bahwa hadits Nabi Muhammad SAW yang digunakan untuk melarang urban tidak sahih sehingga tidak bisa dijadikan hujjah. Beberapa KUH Perdata di negaranegara Islam yang didasarkan kepada hukum Islam juga menjadikan pendapat Hanbali ini sebagai pegangan. Misalkan, dalam Kitab Undang-Undang Hukum Muamalat Uni Emirat Arab Pasal 148 dan Kitab Undang-Undang Hukum Perdata Irak pasal 92 ditegaskan bahwa pertama, pembayaran urban dianggap sebagai bukti bahwa akad telah final dimana tidak boleh ditarik kembali kecuali apabila ditentukan lain dalam persetujuan atau menurut adat kebiasaan. Kedua, bahwa apabila kedua belah pihak sepakat pembayaran urban adalah sebagai sanksi pemutusan akad, maka masing-masing pihak mempunyai hak menarik kembali akad. Apabila yang memutuskan akad adalah pihak yang membayar urban, ia kehilangan urban. Apabila yang memutuskan akad adalah pihak yang menerima urban, ia mengembalikan urban ditambah sebesar jumlah yang sama (Anwar, 2007: 248).

Ketentuan ini memperlihatkan adanya dua tujuan urban yaitu pertama, urban dimaksudkan sebagai bukti untuk memperkuat akad, dimana akad tidak boleh diputuskan sebagai bukti untuk memperkuat akad dimana akad tidak boleh diputuskan secara sepihak oleh salah satu pihak selama tidak ada persetujuan atau adat kebiasaan yang menentukan lain. Kedua, urban dimaksudkan sebagai pemberian hak kepada masing-masing pihak untuk memutuskan akad secara sepihak dalam jangka waktu yang ditentukan dalam adat kebiasaan atau yang disepakati oleh para pihak sendiri dengan imbalan urban yang dibayarkan. Apabila yang memutuskan akad adalah pihak pembayar urban, maka ia kehilangan urban tersebut (sebagai kompensasi pembatalan akad) yang dalam waktu yang sama menjadi hak penerima urban. Sebaliknya, apabila pihak yang memutuskan akad adalah pihak penerima urban, ia wajib mengembalikan urban yang telah dibayar mitranya, disamping tambahan sebesar jumlah urban tersebut sebagai kompensasi kepada mitranya atas tindakannya membatalkan akad (Anwar, 2007: 248249).

Konsep uang muka atau urban dalam Fatwa Dewan Syariah Nasional, lebih cocok dikategorikan sebagai ganti rugi berdasarkan kesepakatan dengan pembayaran awal dari pada konsep urban yang dikenal dalam literatur fiqih pada umumnya dengan alasan pertama, pemotongan urban atau uang muka oleh LKS dalam hal nasabah membatalkan akad murabahah didasarkan pada besarnya kerugian yang dialaminya, sehingga apabila urban itu lebih besar dari pada kerugian LKS, sisanya dikembalikan kepada nasabah dan apabila lebih kecil, LKS dapat meminta tambahan kekurangannya. Kedua, dalam konsiderannya, Fatwa Dewan Syariah Nasional tidak menyinggung hadits larangan urban. Ketiga, sebaliknya fatwa tersebut mengutip hadits tentang syarat perjanjian, "kaum muslimin setia kepada syarat-syarat mereka" dan hadits dengan ganti rugi, "tidak boleh 
merugikan diri sendiri dan tidak boleh merugikan orang lain" (Anwar, 2007: 350-351).

Dari apa yang dikemukakan diatas tampak bahwa akad yang semula mengikat bagi kedua belah pihak berubah menjadi akad yang tidak mengikat karena adanya urban yang ditujukan untuk menjadi imbalan atas pemutusan akad secara sepihak. Dengan demikian tampak pula bahwa urban merupakan sarana melalui pemutusan akad dilakukan. Dalam Fatwa Dewan Syariah Nasional, dikenal juga istilah urban dengan sebutan uang muka. Pembayaran uang muka ini dapat diberlakukan dalam akad pembiayaan murabahah antara sebuah Lembaga Keuangan Syariah (LKS) dengan nasabahnya. Ketentuan tersebut dapat dilihat dari Amar kedua Fatwa DSN yang bunyinya adalah sebagai berikut bahwa jika uang muka memakai kontrak urban sebagai alternatif uang muka maka pertama, jika nasabah memutuskan untuk membeli barang tersebut, maka nasabah tinggal membayar sisa harga. Kedua, jika nasabah batal membeli, uang muka menjadi milik bank maksimal sebesar kerugian yang ditanggung oleh bank akibat pembatalan tersebut, dan jika uang muka tidak mencukupi, nasabah wajib melunasi kekurangannya.

Uang muka tinggal dilihat uang mukanya itu menjadi bagian dari keseluruhan pembiayaan ataukah tidak. Jika uang muka ini menjadi bagian dari seluruh pembiayaan termasuk biaya pokok dalam akad tersebut maka ulama mengatakan boleh, adapun besaran masalah uang mukanya berapa tergantung kesepakatan kedua belah pihak. Jadi seluruh ulama mengatakan yang mayoritas ulama mengatakan boleh adanya uang muka bahkan di bab fiqih dibahas sendiri tentang hukum dari uang muka yang membedakan hanya pada status dari uang muka itu, apakah uang muka itu menjadi bagian dari pembiayaan keseluruhan atau justru uang muka itu hanya sebatas biaya-biaya yang ternyata menguap gitu kan sementara biaya pokoknya tetap gitu.

Dengan demikian menurut analisis penulis, uang muka dalam akad murabahah pada KPR di BNI Syariah adalah merujuk pada Fatwa DSN-MUI Nomor 13 Tahun 2000 tentang uang muka dalam murabahah. Tampaknya fatwa tersebut dipengaruhi oleh pemikiran/pendapat Imam Ahmad beserta para pengikutnya yang membolehkan transaksi jual beli dengan menggunakan uang muka, kemudian merujuk pada peraturan yang sudah ada dari OJK, regulator dari BI bahwa setiap pembiayaan baik konvensional maupun syariah itu harus ada uang muka. Di BNI Syariah uang muka beragam tergantung cashback-cashbacknya, tetapi dalam pembayarannya bank mengutamakan nasabah sebagai pembeli menyimpan dana uang muka terlebih dahulu di BNI Syariah, tetapi setiap penjual itu beragam misalkan meminta pembayaran sekian. Tetepi bank melonggarkan sebagian uang muka, asalkan melalui transfer tidak menerima cash dan bukti transfer sesuai dengan nilai uang muka tersebut sesuai dengan kesepakatan serta surat keputusan pembiayaan tarik tunai uang. Bank sebelum terjadi akad akan memintakan sertifikat terlebih dahulu kepada penjual untuk dilakukan pengecekan di kantor notaris BNI Syariah, karena terkadang penjual takut memberikan sertifikat karena tidak ada jaminan. Sebab itu bukti transfer uang muka diberikan kepada penjual, nanti pihak bank hanya membayar sisa kekurangan sesuai dengan plafonnya.

\section{KESIMPULAN}

Berdasarkan hasil penelitian dan pembahasan yang telah diuraikan pada bab sebelumnya, maka penulis dapat menarik beberapa kesimpulan sebagai berikut:

1) Uang muka dalam akad murabahah pada KPR di BNI Syariah adalah merujuk pada Fatwa DSNMUI Nomor 13 Tahun 2000 tentang uang muka dalam murabahah. Tampaknya fatwa tersebut dipengaruhi oleh pemikiran/pendapat Imam Ahmad beserta para pengikutnya yang membolehkan transaksi jual beli dengan menggunakan uang muka, kemudian merujuk pada peraturan yang sudah ada dari OJK, regulator dari BI, bahwa setiap pembiayaan baik konvensional maupun syariah harus ada uang muka.

2) Setiap pembiayaan pastilah memiliki resiko akan bermasalah atau tidak kembali yang biasa 
disebut pembiayaan macet. Didalam Bank BNI Syariah, upaya dalam menyelesaikan masalah pembiayaan bermasalah atau macet ini pun dilakukan dengan beberapa cara, antara lain: pertama, langkah pembiayaan bermasalah dengan penagihan melalui alat komunikasi, tatap muka dan reconditional. Kedua, langkah pembiayaan macet dengan sistem lelang dan hapus buku atau pemblokiran rekening.

3) Melakukan transaksi akad murabahah dengan konsep Down Payment atau urban secara hukum Islam dibenarkan, karena sifat hukumnya yang khilafiyah dan tidak pasti (zhanni). Ketentuan hukum dalam khazanah fiqih klasik bersifat ijtihad, sehingga perlu konstekstualisasi hukum melalui kajian ijtihad sehingga dapat disimpulkan bahwa dalam transaksi ekonomi saat ini, eksistensi Down Payment dapat memberikan kemudahan dalam transaksi perbankan saat ini. Adanya verifikasi terhadap hadits yang melarang juga dijadikan dasar tentang ketidakmutlakan hukum haram terhadap praktik urban.

\section{DAFTAR PUSTAKAN}

Adam, Panji. “Analisis Terhadap Fatwa Dewan Syariah Nasional (DSN) MUI Nomor 13 Tahun 2000 Tentang Uang Muka Dalam Murabahah". Jurnal Prosiding SnaPP2017 Sosial, Ekonomi, dan Humaniora. Vol 7. No. 3. Th. 2017. Fakultas Syariah Universitas Islam Bandung. Bandung. 2017.

Ali Sakti, Darsono. Dkk. Dinamika Produk dan Akad Keuangan Syariah di Indonesia. Depok: PT Rajagrafindo Persada. 2017.

Antonio, Muhammad Syafi'i. Bank Syariah dari Teori ke Praktek. Jakarta: Gema Insani. 2001.

Anwar, Syamsul. Hukum Perjanjian Syariah, Studi tentang Teori Akad dalam Fikih Muamalat. Jakarta: Raja Grafindo Persada. 2007.

Azwar, Saifuddin. Metode Penelitian. Yogyakarta: Pustaka Pelajar Offset. 1998, Cet. I. 2009.

BNI Syariah, "Griya iB Hasanah", https://www.bnisyariah.co.id/idid/personal/ pembiayaan/bnigriyaibhasanah, Diunduh tanggal 12 Agustus 2020, Jam 08.55 WIB.

BNI Syariah, "Sejarah Perusahaan", https://www.bnisyariah.co.id/idid/perusahaa $\mathrm{n} /$ tentangbnisyariah/sejarah, Diunduh tanggal 28 Juli 2020, Jam 10.50 WIB.

BNI Syariah, Website www.BNISyariah.co.id, Diunduh tanggal 28 Juli 2020, Jam 09.55 WIB.

Departemen Agama. Syamil Qur'an: Cordova AlQur'an dan Terjemahan, Bandung. Kementrian Agama Republik Indonesia. 2012.

Fatimah, Laelatul. "Analisa Penerapan Dp (Uang Muka) Dan Denda Keterlambatan Pembayaran Cicilan Pada KPR Syariah Dengan Akad Murabahah" Studi Kasus: Bank BTN Syariah Cabang Tega. Skripsi tidak diterbitkan. Jurusan Perbankan Program Studi Ekonomi Syariah Sekolah Tinggi Agama Islam (STAI) Pelita Bangsa Bekasi. Bekasi. 2017.

FORDEBI, ADESy. Ekonomi dan Bisnis Islam: Seri Konsep dan Aplikasi Ekonomi dan Bisnis Islam. Jakarta: Rajawali Pers. 2016.

Frank E. Vogel dan Samuel L. Hayes, Hukum Keuangan Islam: Konsep, Teori dan Praktik, Penerjemah: M. Sobirin Asnawi, Dkk. Bandung: Nusamedia. 2007.

Furchan, Arief. Pengantar Metode Penelitian Kualitatif. Surabaya: Usaha Nasional. 1992.

Gunawan, Imam. Metode Penelitian Kualitatif Teori Dan Praktik. Jakarta: Bumi Aksara. 2014.

Hadi, Sutrisno. Metodologi Research Jilid I". Yogyakarta: ANDI. 2004.

Hasibuan. Management Sumber Daya Manusia: Edisi Revisi. Jakarta: Bumi Aksara. 2008.

Hayyie Al Kattani, Abdul. Fiqih Islam Wa Adillatuhu. Jakarta: Gema Insani. 2011.

Heykal, Mohamad. "Analisis Tingkat Pemahaman KPR Syariah Pada Bank Syariah Di Indonesia: Studi Pendahuluan". BINUS Business Review Vol. 5 No. 2 November 2014: 519-526.

Hidayat, Enang. Fiqh Jual Beli. Bandung: PT. Remaja Rosdakarya. 2015. 
Ibnu Majah. Sunan Ibnu Majah. Jilid II. hadits No. 2185. 737.

Idri. Hadis Ekonomi, Ekonomi dalam Perspektif Hadits Nabi. Jakarta: Prenademia Group. 2016.

Ikrar Panyompari, Maspiana Andi. "Analisis Fatwa DSN Murabahah, Diskon Dan Uang Muka". Skripsi tidak diterbitkan. Jurusan Perbankan Syariah Fakultas Ekonomi Dan Bisnis Islam Institut Agama Islam Negeri Pare-Pare. ParePare. 2019.

Ismail. Perbankan Syariah. Jakarta: Kencana. 2017.

Karim, Adiwarman. Bank Islam: Analisis Fiqh dan Keuangan. Jakarta: PT Raja Grafindo Persada. 2003.

Laporan Keuangan BNI Syariah Tahun 2019, "Leading Tranformational Change", www.BNISyariah.co.id, Diunduh tanggal 28 Juli 2020, Jam 08.55 WIB.

Mardani. Figh Ekonomi Syariah. Jakarta: Kencana Pranademedia Group. 2012.

Marwini. "Aplikasi Pembiayaan Murabahah Produk KPRS Di Perbankan Syariah". Jurnal Al-Ihkam Vol. 8 No. 1 Juni 2013. Institut Studi Keislaman Darussalam Gontor. Ponorogo.

Midisen, Kisanda. Wawancara Ahli Hukum Syariah, Bekasi, tanggal 19 September 2020, Jam 13.00 WIB.

Moleong. Metodologi Penelitian Kualitatif (Edisi Revisi). Bandung: Remaja Rosdakarya. 2014.

Mubarok, Jaih. Perkembangan Fatwa Ekonomi Syariah Di Indonesia. Bandung: Pustaka Bani Quraisy. 2004.
Mudrajat Kuncoro, Suhardjono. Managemen Perbankan: Teori Dan Aplikasi. Yogyakarta: BPFE. 2000.

Muhammad. Sistem dan Prosedur Operasional Bank Syariah. Yogyakarta: AMP YPKN. 2002.

Mulyana, Deddy. Metodologi Penelitian Kualitatif. Bandung: Remaja Rosdakarya. 2004.

OJK, "Apa Itu KPR Syariah?", https://sikapiuangmu.ojk.go.id/FrontEnd/C MS/Download/425, Diunduh tanggal 09 Agustus 2020, Jam 22.10 WIB.

Save, M. Dagun. Kamus Besar Ilmu Pengetahuan. Jakarta: Lembaga Pengkajian Kebudayaan Nusantara. 1997.

Setia Prayogo, Dimas. "Analisis Kredit Pemilikan Rumah (KPR) Dengan Akad Pembiayaan Murabahah Di Bank Muamalat KCP Magelang". Skripsi tidak diterbitkan. Fakultas Ekonomi Dan Bisnis Islam Institut Agama Islam Negeri (IAIN) Salatiga. Salatiga. 2016.

Sugiyono. Metode Penelitian. Bandung: Alfabeta. 2008.

Tanzeh, Ahmad. Metodologi Penelitian Praktis. Yogyakarta: Penerbit Teras. 2011.

Qudamah, Ibnu. al-Mugni. Beirut: Dar al-Ihya alTurast a-Turabi. 1405.

Yuliansyah, Roni. Wawancara FC BNI Syariah KCP JABABEKA Bekasi, tanggal 15 Juli 2020, Jam 09.00 WIB.

Zuhaili, Wahbah. al-Figh al-Islami wa Adillatuh Jilid V. Damaskus: Dar al-Fikr. 2005. 